\title{
THE DYNAMICS OF (PERSONALIZED) PARTY IDENTIFICATION \\ IN THE SECOND ITALIAN REPUBLIC
}

Author: DIEGO GARZIA

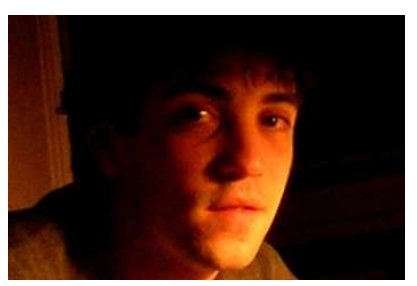

Centre for the Study of Political Change (CIRCaP)

Università di Siena

E-mail: diegogarzia82@virgilio.it

Diego Garzia is PhD candidate in Comparative and European Politics at the University of Siena, Centre for the Study of Political Change (CIRCaP). Previously, he studied at the University of Rome (Sapienza) and Leiden University. His research interests include: political psychology, voting behavior, leadership, and the role of personality in political behavior.

\begin{abstract}
Previous literature (e.g., McAllister 2007) has plainly assumed that the 'personalization of politics' in Western democracies is in large part due to the widespread 'partisan dealignment' going on in these societies. This paper provides an assessment of the causal relationship between these two phenomena in the Second Italian Republic, attempting to demonstrate that partisan dealignment is caused by - and not a cause of - the personalization of politics. Alternative explanations for the rapid weakening of partisan ties in the period 1994-20o8 will be evaluated; then, it will be shown the prominence of leaders' image among the determinants of individual (de)alignment with political parties; finally, it will be revealed how a generalized decrease in the number of partisan is linked to the (equally generalized) deterioration of the overall image of political leaders.
\end{abstract}

KEYWORDS: Personalization of politics, institutional changes, party erosion, party dealignment, leadership, erosion of cleaveges, party system breakdown, elections. 


\section{CAUSES (OR CONSEQUENCES?) OF THE PERSONALIZATION OF POLITICS}

Whether or not the dynamics of parliamentary elections have become more 'presidential' (Mughan 2000; Poguntke and Webb 2005), it is hard to deny that democratic politics is now more 'candidate-centred' (Wattenberg 1991) than ever before. Third-millennium parties' profiles have become undoubtedly more personalized than they were three or four decades ago (Farrell and Webb 2000). The changing structure of mass communications has been crucial in emphasizing the role of political leaders at the expenses of parties, making the latter "more dependent in their communications with voters on the essentially visual and personality-based medium of television" (Mughan 2000: 129). Executives themselves are portrayed in a personalized fashion, being routinely labeled after the name of their leaders (Bean and Mughan 1989), and stronger correlation overtime between prime ministerial popularity and executive's public rating was revealed in several parliamentary democracies (Lanoue and Headrick 1994; McAllister 2003; Campus and Pasquino 2006). Correspondingly, party leaders have been found to matter more in individuals' voting behavior (Stokes 1966; Butler and Stokes 1974; Clarke et al. 1979; Graetz and McAllister 1987; Bean and Mughan 1989; Bean 1993; Crewe and King 1994; Sani 2002; but see King 2002).

The personalization of politics should be seen as a process in which "the political weight of the individual actor in the political process increases over time, while the centrality of the political group (i.e., political party) declines" (Rahat and Sheafer 2007: 65). Three intertwined causes have been advanced for such process of personalization (McAllister 2007). One originates from the institutional setting of the country. The electoral reforms of the 1990 s in countries such as Israel, Italy, and Japan (Shugart and Wattenberg 2001), and the spread of primary elections around Europe (Hazan 2006) are good examples of institutional changes promoting personalization. However, a recent comparative study has found substantive evidence of "a shift in intra-executive power to the benefit of the head of government" (Poguntke and Webb 2005: 337) also in countries where no significant institutional change took place. The second (yet more visible) cause of personalization of politics is the growth of electronic media - and that of television in particular. Because of its power to present images, it is easier for television to communicate political information through physical objects such as leaders (rather than through abstract entities like parties, manifestos or ideologies). Personalization has been defined as "the more general, pervasive, and fundamental element in the process of change of electoral campaigns" (Swanson and Mancini 1996). Finally, the personalization of politics is thought to be caused by the widespread erosion of party loyalties encountered in almost every advanced industrial democracy (Dalton and Wattenberg 2000). In times of partisan dealignment, it is reasonable 
The Dinamics of (Personalized) Party Identification in the Second Italian Republic - Diego Garcia

to hypothesize that "voters will rely more heavily on the appeal of the personalities of the leaders" (McAllister 2007: 582).

The Italian case is probably one of the best examples of personalization among Western European democracies. The origins of this process has been traced to the early-1980s, when the customary division of power between party leadership and the prime minister's office was challenged by figures such as Giovanni Spadolini and Bettino Craxi, which have been the first to hold both the leadership of their parties (PRI and PSI respectively) and the presidency of the Ministers' Council. However, it is only with the transition to the so-called Second Republic that Italy becomes under many respects the ideal-typical 'personalized polity' (Calise 2004). The collapse of the old partitocrazia - weakened by an erosion of the stable social cleavages on which it was based (Parisi and Pasquino 1977) and further discredited by Mani Pulite scandals (Gilbert 1995) - produced the most appropriate conditions for popular figures to 'enter the field'. Moreover, the majoritarian reform of the electoral systems for both local (Fabbrini 2000) and national elections (Katz 2003) "strongly reinforced the view that people would henceforward directly decide on political outcomes" (Calise 2005: 90). With respect to political communication, it is true that television coverage was already shifting towards the candidates during the 1980s. Yet the entrance of Silvio Berlusconi (then owner of three out of six national TV-channels) in Italian politics resulted, according to many, in an unprecedented acceleration of such trend (Campus and Pasquino 2006). Thanks to the success of his 'media party' Forza Italia (Perrucci and Villa 2004), he made the others' increasingly dependent from television, for it immediately "seemed clear that no party could remain in the contest without heavy use of mass communication channels" (Mazzoleni 1996: 200). The extent to which Italian electoral campaigns have become more personalized is evident from the adoption of televised election debates all'Americana, which were held in 1994, 1996 and 2006 ${ }^{1}$. Furthermore, the resilience of Silvio Berlusconi (uncontested leader of the centre-right coalition) and Romano Prodi (Prime Minister twice: in 1996-8 and 2006-8) on the political scene contributed in making the past decade "something of a duel between two leaders" (Cotta and Verzichelli 2007: 64).

While both institutional change and television had a plain role in the personalization of the Second Italian Republic, the causal role of partisan dealignment is much less clear. It is true that the erosion of partisan ties was among the main determinants of party system breakdown (Morlino 1996); and in fact the election of 1994 was held at the nadir of party identification in the country (Bellucci 2007). However, it must be noted that only two years

\footnotetext{
${ }^{1}$ Not in 2001 though, when in order to challenge Berlusconi on his major strength (e.g. personal appeal) the centre-left coalition nominated the young, good-looking and relatively inexperienced Francesco Rutelli as its prime ministerial candidate, instead of incumbent prime minister Giuliano Amato (Calise 2005).
} 
The Dinamics of (Personalized) Party Identification in the Second Italian Republic - Diego Garzia

later the Italian electorate was almost completely realigned, with three voters out of four reporting a feeling of identification with a party (ITANES 1996). The aim of this paper is to uncover the determinants of partisan dealignment in the Second Italian Republic ${ }^{2}$. As we will try to show, this is to be found in the public's assessment of party leaders: in absence of widespread information about the new parties (as it was the case with the 'old' parties), voters developed a sense of party identification based on the only feature they could manifestly evaluate: the parties' leaders. Given the already high degree of personalization in the political system, the subsequent fall in the number of partisans (minus twenty-five percent in the decade 1996-2006) can hardly be conceived as a cause of personalization.

Rather, this paper is aimed to verify whether the causal relationship between partisan dealignment and the personalization of politics in the Second Italian Republic operates the other way around. In other words, my hypothesis is that in our case partisan dealignment is caused by - and not a cause of - the personalization of politics. There are several grounds to base this expectation. The 'indistinguishable identity' between the leader and the party (Poli 2001) that always denoted Forza Italia, paralleled by an increasing number of 'personal parties' (Calise 2000) support the contention that in post-1994 Italy political leaders have become important in their own right "by personifying the policy platforms of their respective parties" (McAllister 2007, 574). This claim is further reinforced by the consideration that every political leader of the Second Republic has been in politics longer than his own party3. The predominant position of Italian leaders vis à vis their parties emerges clearly with a quick glance to the ballot paper, where the great majority of party symbols feature the name of the respective leaders as big as it fits ${ }^{4}$.

Our hypothesis will be verified in the following way: first, alternative explanations for the rapid weakening of partisan ties in the past fifteen years will be evaluated; secondly, the properties of party identification as an analytical construct will be assessed in order to ascertain that the concept 'traveled well' into the Second Republic; at third, it will be demonstrated the prominence of leaders' image among the determinants of individual (de)alignment with political parties; if partisanship is caused mostly by the image of the leaders, then we might expect that a generalized decrease in the number of partisan is linked to an equally generalized deterioration of the overall image of political leaders - this proposition will be tested in the final section of the analysis.

\footnotetext{
${ }^{2}$ For the purposes of this study, we will consider post-1994 Italy as an intrinsically different political system from the one that preceded it - that is, the First Italian Republic. Hence, our explanation of partisan dealignment in the Second Republic does not (and cannot) account for a similar process (e.g., partisan dealignment) in a different setting (e.g., pre-1994 Italy).

${ }^{3}$ Of course, this assertion holds only as long as we take a nominalist approach to parties.

${ }^{4}$ Some observers considered this as an unprecedented step in parliamentary regimes that declares the penetration of the presidential criteria even in the electoral device (Calise 2004: 32).
} 


\section{PATTERNS OF PARTISAN DEALIGNMENT IN THE SECOND ITALIAN REPUBLIC}

Figure 1 presents the percentage of party identifiers in the period 1996-20085. As said, the electorate was significantly realigned after only two years from the fall of the old party system (e.g., 1994). However, the decline in the period 1996-2001 is somehow impressive, with the percentage of survey respondents declaring a sense of identification with a political party falling steadily from seventy-seven percentage points to fifty-five (minus 22 percent). The decrease is even more striking among 'strong partisans', that go down from 18,4 to 11,2 percentage points (that is, some forty percent less). Between 2001 and 2008 the tendency towards further dealignment slows down considerably, yet the proportion of partisans keeps going down (53 percent in 2006, 51,5 percent in 2008) along with that of strong partisans $(10,7$ percent in $2006,7,8$ percent in 2008).

FIGURE 1 - Party Identifiers (\%) 1996-2008

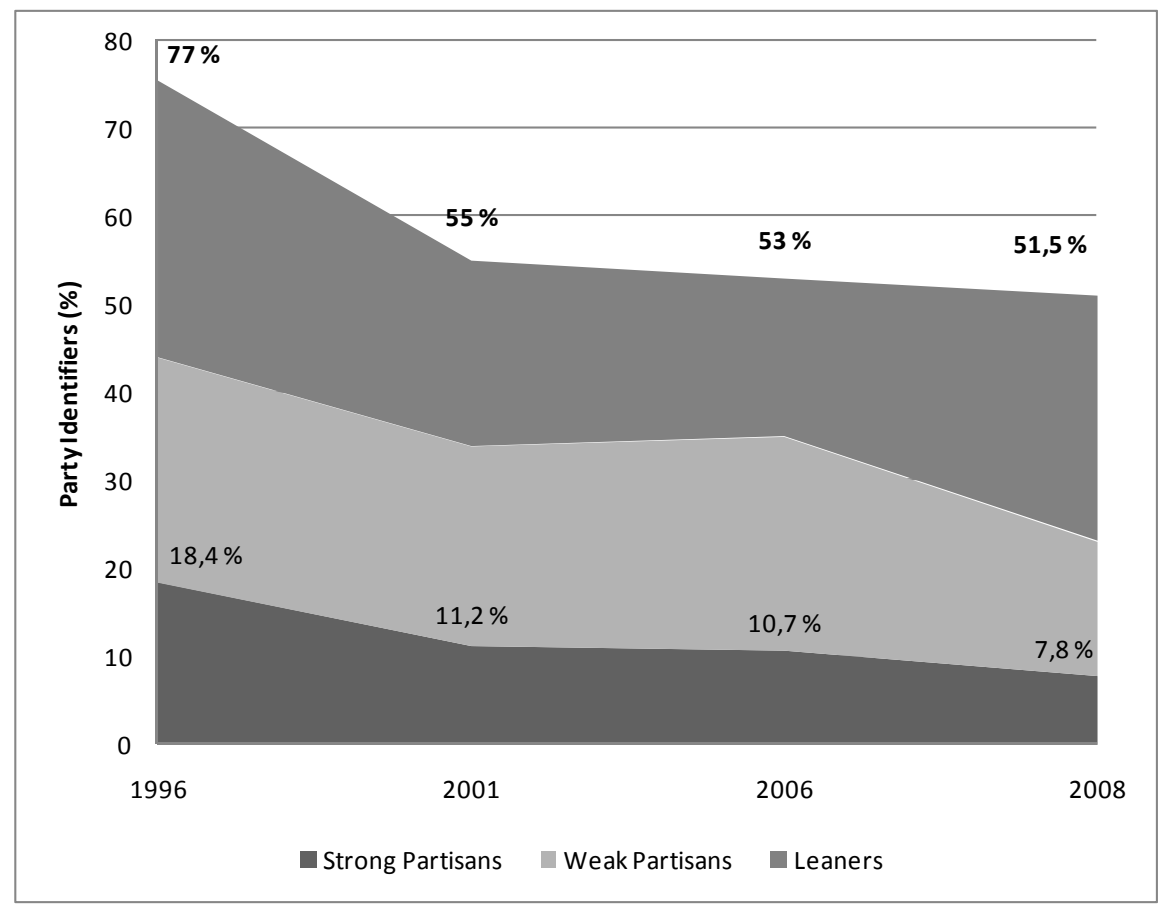

SOURCE: ITANES 1996, 2001-2006 (Panel), 2008

To be sure, partisan dealignment is not an Italian peculiarity. The widespread decline of partisan attachments occurred across all Western democracies in the past several decades has been described as the most profound change in voting behavior since the 1920s (Dalton and Wattenberg 2000). Dalton (1984) interpreted it as a consequence of the process of modernization going on in every advanced industrial democracy. Building on the 'functional model' of party identification - that implies the need for partisan ties to be a function of

\footnotetext{
${ }^{5}$ Unfortunately, ITANES (Italian National Election Study) investigators did not pose the question in 1994.
} 
The Dinamics of (Personalized) Party Identification in the Second Italian Republic - Diego Garzia voters' political skills and information (Shively 1979) - he showed that the dramatic spread of education along with a generalized information explosion in these countries significantly improved the average citizen's political and cognitive resources. This cognitive mobilization entails that "citizens possess the skills and resources necessary to become politically engaged with little dependence on external cues" (Dalton 1984: 267). It follows that a pattern of partisan dealignment should be accentuated among the better educated and those more exposed to the information flow of the media (that is, the young). Such pattern has been observed in almost every advanced industrial society, including the First Italian Republic (Dalton 2000).

As shown above, the Second Italian Republic saw a steady and unambiguous process of partisan detachment, and we know this finding to be in line with modernization theory. Yet, "even if the development of the level of party identification is consistent with what the theory of modernization predicts, this does not necessarily prove that this development is caused by the mechanisms supposed in functional theory" (Berglund et al. 2005: 108). We can assess the ability of cognitive mobilization theory in explaining the dealignment occurred between 1996 and 2008 through ITANES data. The first two columns of Table 1 present the mean age of partisans and apartisans respectively in each election year (also, the table includes a measurement relative to 2004, when the second wave of a panel study started in 2001 was conducted). The third and the fourth columns report the mean score of partisans and apartisan in each time-point on a simple 'education level index' (respondents are coded: 1primary education; 2-secondary education; 3-high school; 4-college education).

TABLE 1 - Mean Score for Partisans/Apartisans on Alternative Measures of Partisan Dealignment, 1996-2008

\begin{tabular}{|c|c|c|c|c|c|c|c|c|}
\hline & \multicolumn{2}{|c|}{ AGE } & \multicolumn{2}{|c|}{ EDUCATION } & \multicolumn{2}{|c|}{ POLARIZATION } & \multicolumn{2}{|c|}{ PARTY TRUST } \\
\hline & Partisan & Apartisan & Partisan & Apartisan & Partisan & Apartisan & Partisan & Apartisan \\
\hline 1996 & 44,1 & 42,4 & 2,17 & 2,08 & - & - & - & - \\
\hline 2001 & 46,7 & 46,7 & 2,35 & 2,15 & 5,18 & 4,92 & 1,13 & 0,74 \\
\hline 2004 & 50,9 & 49,2 & 2,38 & 2,15 & 5,15 & 4,77 & 1,13 & 0,71 \\
\hline 2006 & 50,2 & 49,8 & 2,53 & 2,31 & 5,04 & 4,36 & 1,12 & 0,79 \\
\hline 2008 & 49,4 & 49,9 & 2,46 & 2,29 & 4,16 & 3,51 & 1,10 & 0,75 \\
\hline $\begin{array}{l}1996-2008 \\
2001-2008\end{array}$ & $\begin{array}{l}+5,3 \\
(+2,7)\end{array}$ & $\begin{array}{l}+7,5 \\
(+3,2)\end{array}$ & $\begin{array}{l}+0,29 \\
(+0,11)\end{array}$ & $\begin{array}{l}+0,21 \\
(+0,14)\end{array}$ & $\begin{array}{c}- \\
-1,02\end{array}$ & $\begin{array}{c}- \\
-1,41\end{array}$ & $\begin{array}{c}- \\
-0,03\end{array}$ & $+0,01$ \\
\hline
\end{tabular}


If we are to believe that the weakening of partisan ties is a function of social modernization, then we expect the 'average apartisan' to be(come) younger and more educated than the 'average partisan' through the years. However, the data hardly support this contention. With respect to age, partisans are in average almost two years older than apartisans in 1996, as old as apartisans in 2001 and some half year younger than the latter in 2008 (the fact that both groups are getting older through the years is easily explained by the demographical structure of a country where one citizen in five is a pensioner). Regarding education, the trend is even clearer: both partisans and apartisans are getting (in average) more educated, and they are doing so in almost equal proportions. In the light of our data, it seems hazardous to conclude that the process of modernization (that is undoubtedly occurring in Italy as in every advanced industrial democracy) is a causal determinant of partisan dealignment. With this we do not intend to point out that the role of macro sociological explanations of the sort is irrelevant. On the contrary, they exert in all likelihood a role as driving forces behind the long(er)-term trend (Holmberg 1994). However, if we are looking for a more satisfactory account of the phenomenon in the short time span of this study (e.g., twelve years), we might want to turn to political explanations.

One of the hypotheses advanced by Berglund et al. (2005) in a recent assessment of party identification in six European democracies maintains that "people's degree of party identification is related to the extent that they perceive ideological differences between relevant political parties" (117). Their findings indicate that perceived polarization is positively (albeit weakly) correlated with people's strength of partisan attachment in each of the countries under analysis. In order to test this hypothesis on our case at hand, we have calculated for each respondent the perceived distance on the left-right spectrum between the main two Italian parties (1994-2006: Forza Italia and Democratici di Sinistra; 2008: Popolo della Libertà and Partito Democratico). In the fifth and sixth column of Table 1 is presented the mean score for both partisans and apartisans on this 'polarization' variable in each time point (except 1996, for in that year respondents were not asked by ITANES investigators to position parties on the classical ten-points scale). On the one hand, it appears clearly that partisans perceive the two main parties to be more distant than do the apartisans - and this is true in each year investigated. On the other hand, it also must be noted that both groups show to perceive an increasing depolarization between the two parties. The figures move downwards very slowly between 2001 and 2006 though, while the major decrease is found between 2006 and 20086. Overall, we find weak support for the 'depolarization hypothesis' within the context of the Second Italian Republic. It is true that partisans perceive a higher

\footnotetext{
${ }^{6}$ This is hardly surprising, given that the process culminated in the foundation of PD and PdL was based on the implicit - and unrealized - expectation that the two would have been the only actors of the bi-party system to come (hence, both aimed at the exploitation of the centre).
} 
The Dinamics of (Personalized) Party Identification in the Second Italian Republic - Diego Garzia degree of polarization among the main parties as compared with apartisans, but it is also evident that both groups increasingly perceive a depolarization in the party system. To be sure, the multivariate analysis presented in the forthcoming section will show that among panel respondents, the perception of a lower degree of polarization at $t_{2}$ (as compared with $t_{1}$ ) is a statistically insignifcant predictor of partisan instability/dealignment.

As a final test, we will verify whether partisan ties' decline is indeed a sign of growing disenchantment with political parties as agents of representative democracy (Dalton 2004; Dalton and Weldon 2004). The entries presented in the last two columns of Table 1 represent the mean score of partisans and apartisans respectively on a 'party trust index' (coding: o-not [trust] at all; 1-little; 2-somewhat; 3-very much). Once again, there is no supporting evidence in our data. Apartisans do not generally trust political parties (in average, they trust political parties less than 'a little') but they do not show to trust parties less with time (the mean score on the index being almost equal in both 2001 and 2008). Partisans do not have a much better image of parties though (the score indicating an average level of trust slightly higher than 'a little'), and like apartisans their score does not differ significantly during the decade under analysis (also this hypothesis will be tested in the forthcoming section, so as to assure us that decreasing trust in political parties at the individual level bear no causal impact on partisan detachments).

This section has demonstrated that the steady erosion of partisan ties among voters of the Second Italian Republic cannot be satisfactorily explained with theories such as cognitive mobilization (Dalton 1984), depolarization (Holmberg 1994) or declining trust (Dalton and Weldon 2004). Once freed from competing explanations of partisan dealignment, we are now left with the task of demonstrating that the main cause of the process is to be found in the personas of the party leaders. Before doing so, however, we will first verify the applicability (and the characteristics) of party identification as an analytical concept in the Second Italian Republic.

\section{PARTY IDENTIFICATION ITALIAN STYLE}

Since the 1950 s the concept of party identification has been central to the evolution of electoral behavior studies on both sides of the Atlantic. In its original formulation, it is conceived as a "psychological identification, which can persist without legal recognition or evidence of formal membership and even without a consistent record of party support" (Campbell et al. 1960: 121), while its analytical usefulness lies in its "relative stability and priority in time" (ibid. 135) as compared with vote choice. Hence, party identification is (i) distinguishable, (ii) causally antecedent and (iii) more stable than vote choice. The "most enduring of political attitudes" (Miller and Shanks 1996: 117) has nevertheless been widely 
criticized on several grounds. Under the push of rational choice models inspired by Downs, some American scholars questioned the stability of party identification demonstrating that it could be moved even in the short run (Markus \& Converse 1979; Fiorina 1981). Even stronger critiques emerged from the implementation of the concept in the analysis of Europeans' voting behavior. Since the very first attempts it became clear that in countries featuring a tight fit between political parties and social structure, the primary identification is that with the social group. In other words, the stability of partisan identifications should reflect the stability of party-society links (Campbell and Valen 1966). In a comparative assessment of party identification in Europe (Budge et al. 1976), it was demonstrated that the concept 'did not travel well' to the Old Continent (Crewe 1976; Kaase 1976). Thomassen's (1976) analysis of the Dutch case showed that party identification in the Netherlands did not share any of the three 'core properties' as featured in the U.S. Against this view, Holmberg (1994) found in a comparative analysis of Britain, Canada, Sweden, the U.S. and the Netherlands, that in all but the latter party identification was more stable than the vote and - at least in Sweden distinguishable from vote choice.

The aim of this section is to evaluate applicability and properties of party identification in the Second Italian Republic. Before 1994 Italian politics was characterized by a substantial overlap of political parties and social subcultures. However, that year's election resulted in the extinction of the old class-mass parties that ensured the stability of party-society links. Furthermore, the parallel erosion of social cleavages made it hard - or useless, as one prefers - for new parties to appeal to (only) one of the country's subcultures. In the light of this situation, it is not unreasonable to expect that Italian voters (freed from past group loyalties) could develop an 'orthodox' sense of identification with one of the actors of the Second Republic politics. The data to assess the properties of party identification in post-1994 Italy come from ITANES post-electoral panel survey conducted in three waves (2001, 2004, 2006)7. Since we intend to test the stability of a long-term attitude, the relatively wide timespan of the survey makes it perfectly suitable for our analytical purposes. Furthermore, the election of 2001 was the third held in the Second Republic. As we know from the literature, "there is much less malleability [in individuals' party identification] after the third election" (Miller and Shanks 1996: 131). Hence, we are assured that we are studying a period where partisan identities were already shaped in individuals' mind.

i. Consistency of Party Identification and Vote Choice. In 2001 the percentage of identifiers voting consistently with their party identification varied between 87 percent (strong partisans) and 77 percent (leaners). Five years later the figures were slightly higher,

\footnotetext{
${ }^{7}$ Nationwide panel survey conducted through face-to-face interviews/CAPI $[n(2001)=3209 ; n(2004)=1882$; $\mathrm{n}(2006)=1048]$
} 
The Dinamics of (Personalized) Party Identification in the Second Italian Republic - Diego Garzia with 89 percent of strong partisans voting consistently with their party ID (figure lowered to 85 percent among leaners). In line with both American (Campbell et al. 1960; Miller and Shanks 1996) and European findings (Thomassen 1976; Holmberg 1994; Thomassen and Rosema 2009), the stronger the partisan ties, the higher the probabilities of vote for the party one identifies with. More importantly, the percentage of consistent partisan voters stands at a level that did not appear 'too close for comfort' in other European countries such as Sweden (Holmberg 1994: 97). Hence, we can assert that party identification in the Second Italian Republic (at least during the years under scrutiny) is distinguishable from vote choice.

ii. Causal antecedence of party identification. If we compare the percentage of Italian respondents whose party identification in 2001 coincided to their vote in 2006 with those whose vote choice at the beginning of the panel matched with their party identification five years later, we can appreciate that the former group is more numerous than the latter (66 percent against 59 percent). In other words, previous identifications had a stronger causal effect on future vote choices than did previous vote choices on one's future party identification. That is, party identification is causally antecedent to vote choice.

iii. Stability of party identification over time. The third feature of the concept in its original Michigan connotation is, as we have seen, the higher stability when compared to vote choice stability. However, the data in Table 2 hints us that this is not the case in the Italian context. Vote choice has been stable in two respondents out of three (time points: 2001 and 2006), while only one in two declared to be identified with same party after five years from the first interview. The cross tabulation of the two variables shows that, similarly to the Netherlands (Thomassen and Rosema 2009: 50) - and contrary to the 'orthodox' assumption - the number of people with unstable party identification and stable vote choice outnumbers on a 4:1 ratio the amount of respondents with stable identification and unstable vote preference. 
TABLE 2 - Party ID and Vote Choice Stability across Two Elections, 2001-2006

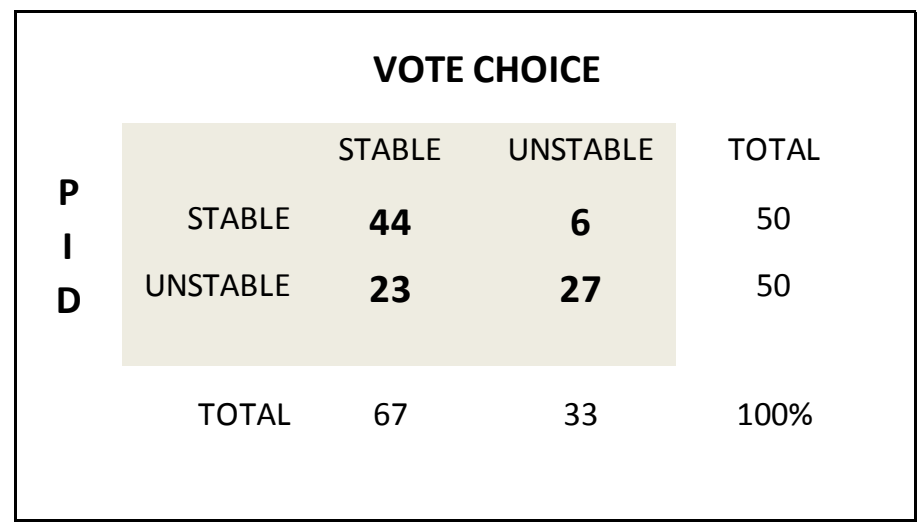

SOURCE: ITANES 2001-2006 (Panel)

Figure 2 sketches in more details the dynamics of party identification through a period of five years. The use of panel data allows us to trace the record of alignment(s) for same individuals across time. The two groups on the left side of the figure represent partisans and apartisans as categorized in 2001 (55 and 45 percent respectively). Each group is then analyzed according to its respondents' partisan status is 2004 and 2006 (by 'unstable partisans' we mean not only those who changed the party they identify with, but also those who reported to not identify anymore with any party). Three points seem worth noting: a) stable partisans are the most likely to remain partisan across time (i.e., 77 percent of stable partisans in 2004 remain partisan in 2006, while among the unstable partisans the percentage of identifiers in the successive time point is only $5^{8}$ percent); b) the majority of unstable partisans is always made of former partisans who do not identify anymore with any of the parties ('quitters' in the figure: between 57 and 65 percent); c) being apartisan means a high likelihood to not become partisan (only one apartisan in three turn to a party in both 2001-4 and 2004-6). Notwithstanding the high instability of partisanship among our sample (and even among stable partisans), it seems clear that unstable partisans are more likely to 'quit' partisanship with time than do stable partisans. The main concern regarding this process lies in the fact that those who turned to apartisanship are also the most likely to not become partisans again. In other words, unstable partisanship is in the long run conductive to dealignment. 
The Dinamics of (Personalized) Party Identification in the Second Italian Republic - Diego Garzia FIGURE 2 - The Dynamics of Party Identification, 2001-2004-2006

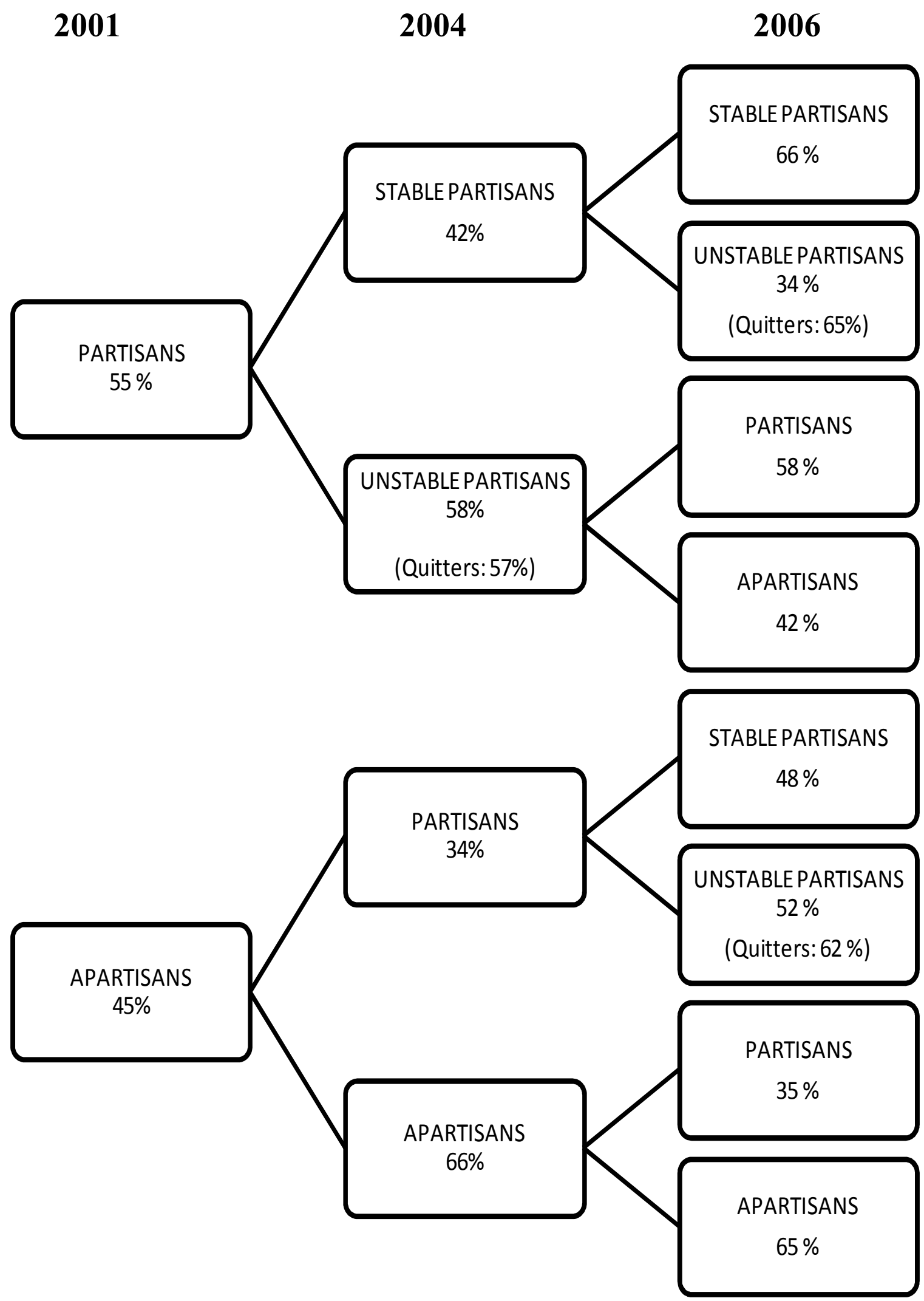

SOURCE: ITANES 2001-2006 (Panel) 
The Dinamics of (Personalized) Party Identification in the Second Italian Republic - Diego Garcia

\section{THE DETERMINANTS OF PARTISAN (DE)ALIGNMENT IN THE SECOND REPUBLIC, 2001-2004}

In this section we will assess in turn the determinants of party identification (static model) and partisanship instability (dynamic model) in the period 2001-4 (that is, the years when the first two waves of ITANES panel were conducted $^{8}$ ).

\subsection{The Determinants of Party Identification, 2001 (Static Model)}

By means of binary logistic regression we can appraise the relative strength of the explanatory variables usually considered to be cause of one's identification with a political party. Two in particular will be at the core of our analysis. We will call them respectively the 'personal component' and the 'political component'. We operationalized the former with the respondent's evaluation (on a 1-to-10 scale) of the party leader, and the latter through the left-right distance between the self and the party ${ }^{9}$ (that is, self-placement's score on the $\mathrm{L} / \mathrm{R}$ scale minus the score assigned to the party on the same scale, in absolute value). The model includes also standard sociodemographic variables (e.g., age, gender, education level, social class, trade union membership, religious attendance and TV exposure). The 'static model' is designed in the following way. Five different regression analyses were performed, one for each of the main parties then in Parliament. In every instance, the dependent variable is a dummy coding $\mathbf{1}$ the respondents identified with that party, and $\mathbf{o}$ apartisans as well as identifiers with parties other than the one under scrutiny. With regard to the predictors, the 'personal component' variable is the respondent's evaluation of the leader of that party, while the 'political component' measures the respondent's distance on the left-right scale with the party for which the regression analysis is being performed. Table 3 presents the standardized regression coefficients (B) of our analyses (entries in italic are not significant at the .05 level).

\footnotetext{
${ }^{8}$ An analysis of the period 1996-2001 would have been preferred, for it was in those years that the major decrease in partisanship took place. However there is no panel data for that period. Hence, I decided to move the analytical focus five years ahead, in order to take advantage of a unique dataset that allows us to assess the determinants of both partisan alignment and partisanship (in)stability across the same individuals (something that could not be done with standard post-election surveys, given the dynamic nature of the analysis).

${ }^{9}$ According to Inglehart and Klingemann (1976), "the classic view of the left-right dimension sees it as a superissue which summarizes the [political] programmes of opposing groups" (244).
} 
TABLE 3 - The Determinants of Party Identification in 2001 (Logistic Regression Estimates)

\begin{tabular}{|c|c|c|c|c|c|}
\hline & $\begin{array}{l}\text { Alleanza } \\
\text { Nazionale }\end{array}$ & $\begin{array}{c}\text { Democratici } \\
\text { di Sinistra }\end{array}$ & Forza Italia & Lega Nord & $\begin{array}{c}\text { Rifondazione } \\
\text { Comunista }\end{array}$ \\
\hline Age & -.01 & - & .01 & .01 & -.03 \\
\hline Gender & -.56 & -.15 & .20 & -.40 & -.42 \\
\hline Education & .36 & -.02 & -.09 & .31 & -.37 \\
\hline Social Class & .19 & -.07 & .05 & -.23 & -.12 \\
\hline Union Member & .13 & .61 & -.32 & -.35 & .12 \\
\hline Religious Attendance & -.10 & - 17 & .03 & -.16 & -.12 \\
\hline TV Exposure & .05 & 01 & -.06 & -.02 & -.17 \\
\hline Political Component & -1.01 & -.98 & -.61 & -.89 & -1.03 \\
\hline Personal Component & .66 & .44 & .67 & .91 & .42 \\
\hline Nagelkerke R Square & .54 & .50 & .49 & .47 & .48 \\
\hline $\begin{array}{l}\text { \% Cases Correctly Predicted } \\
\text { (n) }\end{array}$ & $\begin{array}{c}91,3 \\
(2178)\end{array}$ & $\begin{array}{c}87,3 \\
\quad \quad(2035)\end{array}$ & $\begin{array}{c}85,8 \\
(2231)\end{array}$ & $\begin{array}{c}98,6 \\
(1997)\end{array}$ & $\begin{array}{c}95,8 \\
\quad(2116)\end{array}$ \\
\hline
\end{tabular}

The predictive power of the five models is overall satisfactory (Nagelkerke R Square ranging between .47 and .54; cases correctly predicted between 85,8 and 98,6). We can appreciate the fact that both 'personal' and 'political' components are statistically significant predictors of party identification for every party under analysis. The 'personal component' is the dominant predictor of partisanship in two cases, and not by chance the two most 'personal' parties of the maze: Forza Italia and Umberto Bossi's Lega Nord. In the other three instances, it is indeed the 'political component' the best predictor of alignment with party (e.g., Alleanza Nazionale, Democratici di Sinistra and Rifondazione Comunista). This is hardly surprising, given the more 'political' nature of these parties - all of them were in fact legitimate heirs of mass parties of the previous century (contrary to F.I. and L.N.). Nevertheless, even among these parties the 'personal component' of party identification is a strong determinant of partisanship (the second stronger except for D.S., where it is union membership the most powerful predictor of party identification after the 'political component'). Overall, we can assert that evaluation of the party leader is a very strong (and at times the strongest) determinant of party identification ${ }^{10}$.

\footnotetext{
${ }^{10}$ Some might advance that partisans can be biased in the judgment of their own party's leader, hence inflating the explanatory power of the 'personal component' on identification. However, our analysis has focused on five parties whose leaders in 2001 have been so since the foundation of those parties. Hence we are assured that the ‘indistinguishable identity' between the leader and the party has not been disentangled yet (Poli 2001).
} 
4.2. The Determinants of Partisanship Instability, 2001-2004 (Dynamic Model)

Making use once again of binary logistic regression, we now move to the assessment of the determinants of partisanship instability. As described above, we consider as 'unstable partisans' the voters who changed party they identify with across the two time-points, as well as those who reported a sense of identification in 2001 but not anymore in 2004. The 'dynamicity' of the analysis resides in the fact that we will use differentials as independent variables. That is, the 'personal component' of partisanship instability will be operationalized as the difference between leader evaluation at $t_{2}$ and (same) leader evaluation at $t_{1}$, while the 'partisan component' will be the difference between the self and the (same) party on a leftright scale across the two time-points. The 'dynamic model' features also the individual differential in perceived polarization of the party system (left-right distance between the main two parties) and party trust (score on the three point scale) between $t_{1}$ and $t_{2}$, and of course the group of control variables already employed (e.g., age, gender, education level, social class, trade union membership, religious attendance and TV exposure). This model differs from the 'static' one in the choice of the cases under analysis. While the previous analyzed every respondent of the survey, this one will indeed concentrate on the respondents who declared to be partisans in 2001 but that also took part in the second wave of the panel. Three different regression analyses were performed, this time including only identifiers with the three parties (one regression per each group of partisans) featuring a sufficient number of respondents who was both partisan in 2001 and re-interviewed in 2004 (e.g., Alleanza Nazionale, Democratici di Sinistra, Forza Italia). The dependent variable is a dummy coding 1 those who remained stable partisans between 2001 and 2004, and $\mathbf{0}$ unstable partisans. Table 4 presents the standardized regression coefficients (B) of our analyses (entries in italic are not significant at the .05 level). 
The Dinamics of (Personalized) Party Identification in the Second Italian Republic - Diego Garzia

TABLE 4 - The Determinants of Partisanship Instability, 2001-2004 (Logistic Regression Estimates)

\begin{tabular}{|c|c|c|c|c|}
\hline & & $\begin{array}{c}\text { Alleanza } \\
\text { Nazionale }\end{array}$ & $\begin{array}{l}\text { Democratici di } \\
\text { Sinistra }\end{array}$ & Forza Italia \\
\hline Age & & -.02 & -.04 & .02 \\
\hline Gender & & .09 & -.51 & .09 \\
\hline Education & & .23 & .32 & .23 \\
\hline Social Class & & .23 & -.18 & -.07 \\
\hline Union Member & & -1.10 & .50 & .40 \\
\hline Religious Attendance & & -.29 & -.16 & -.08 \\
\hline TV Exposure & & .53 & .04 & .11 \\
\hline Polarization (Diff.) & & -.19 & .03 & -.02 \\
\hline Trust in Parties (Diff.) & & .14 & -.04 & .09 \\
\hline Political Component (Diff.) & & -.59 & -.28 & -.31 \\
\hline Personal Component (Diff.) & & .77 & .25 & .42 \\
\hline Nagelkerke R Square & & .56 & .31 & .38 \\
\hline $\begin{array}{l}\% \text { Cases Correctly Predicted } \\
\text { (n) }\end{array}$ & $\boldsymbol{\nabla}$ & $\begin{array}{l}81,2 \\
(133)\end{array}$ & $\begin{array}{r}71,2 \\
(170)\end{array}$ & $\begin{array}{l}73,7 \\
(190)\end{array}$ \\
\hline
\end{tabular}

The estimates of our analysis marshal strong support to our research hypothesis. In every group of partisans under scrutiny it is the 'personal component' the strongest determinant of partisanship instability, and indeed the only predictor which remains statistically significant across groups (the 'political component' looks stronger in the case of D.S., but the coefficient is not significant). That is, a worsened evaluation of the leader bears a stronger effect as compared with a perceived increase between one's left-right placement and that of the party. Also, we can appreciate the fact that none of the usual suspects of partisan dealignment (e.g., age, education, depolarization and party trust) bear a visible impact on partisanship instability.

Our findings thus demonstrate that partisan dealignment in the Second Italian Republic is better explained as a process where the (changing) image of party leaders is central in provoking partisanship instability, which is in turn conductive to apartisanship (as showed above). As partisan alignment is mainly a function of one's evaluation of the party leader, by the same token dealignment is caused, first and foremost, by a deteriorated perception of him. That is, partisan (de)alignments are caused for the most part by the voters' evaluation of party leaders. 


\section{PARTISAN DEALIGNMENT AND THE 'OVERALL IMAGE OF LEADERS’}

In the previous section, the prominence of leaders' image among the determinants of individual (de)alignment with political parties has been revealed. In a context in which partisanship is mainly a function of the image of the leaders (as perceived by the voters), we might hypothesize that a generalized erosion of partisan ties at the aggregate level is in relationship with a parallel deterioration of the overall image of party leaders. The high instability of partisan ties among Italian voters (hand in hand with the key role exerted by party leaders' image in determining both party identification and partisanship instability) implies that 'unstable partisans' are still available in considering new parties to identify with, but only as long as they see other party leaders in a sufficiently favorable way. In the light of this, it follows that a worsened evaluation of party leaders as a whole strongly reduces the likelihood for such 'unstable partisans' to find a spot to realign. Table 5 presents the mean score assigned by survey respondents to party leaders of the bigger eight parties in each election year (plus 2004, where the parties considered are the same of 2001). What concerns us the most here are the entries in the last row of the table, that represent the mean score of party leaders as a whole in each time-point (that is, the 'overall image of leaders'). Despite the fact that in no case party leaders as a whole are evaluated sufficiently (mean scores all below the score of six), there is nonetheless a substantive variance throughout the period 1994-2008. The "overall image of leaders" rises of a half-point between 1994 and 1996 (when it hits the highest peak of the period). Then, a steady decline in the period 1996-2004 (lowest dip of the series) is followed by a nearly equivalent increase between 2004 and 2008 (when the overall score of leaders backs close to 1996 levels). 
The Dinamics of (Personalized) Party Identification in the Second Italian Republic - Diego Garzia

TABLE 5 - Mean Evaluation of Eight Party Leaders and 'Overall Image of Leaders', 1994-2008

\begin{tabular}{|lccccccc|}
\hline & $\mathbf{1 9 9 4}$ & $\mathbf{1 9 9 6}$ & $\mathbf{2 0 0 1}$ & $\mathbf{2 0 0 4}$ & $\mathbf{2 0 0 6}$ & $\mathbf{2 0 0 8}$ & MEAN \\
Prodi & - & 6,2 & - & - & - & - & 6,2 \\
D'Alema & - & 6,2 & - & - & - & - & 6,2 \\
Fini & 5,5 & 5,9 & 5,9 & 5,5 & 5,5 & 5,8 & 5,7 \\
Veltroni & - & - & 5,2 & - & - & 5,9 & 5,5 \\
Berlusconi & 6,9 & 5,3 & 5,9 & 4,0 & 4,5 & 5,6 & 5,4 \\
Dini & - & 5,3 & - & - & - & - & 5,3 \\
Casini & - & 4,8 & 4,9 & 4,9 & 5,3 & 5,3 & 5,0 \\
Rutelli & - & - & 5,3 & 4,4 & 5,0 & - & 4,9 \\
Fassino & - & - & - & 4,6 & 5,0 & - & 4,8 \\
Bertinotti & 4,3 & 5,7 & 4,6 & 4,6 & 4,9 & 4,5 & 4,8 \\
Segni & 4,7 & - & - & - & - & - & 4,7 \\
Di Pietro & - & - & 4,4 & 3,8 & - & 5,4 & 4,5 \\
Pannella & 4,4 & - & - & - & - & - & 4,4 \\
Martinazzoli & 4,3 & - & - & - & - & - & 4,3 \\
Occhetto & 4,3 & - & - & - & - & - & 4,3 \\
Pecoraro Scanio & - & - & - & - & 4,2 & - & 4,2 \\
Santanchè & - & - & - & - & - & 4,2 & 4,2 \\
Bossi & 3,6 & 3,4 & 3,0 & 2,9 & 3,2 & 4,6 & 3,4 \\
OVERALL LEADER IMAGE & 4,8 & $\mathbf{5 , 3}$ & $\mathbf{4 , 9}$ & $\mathbf{4 , 3}$ & $\mathbf{4 , 7}$ & $\mathbf{5 , 2}$ & \\
\hline
\end{tabular}

SOURCE: ITANES 1994, 1996, 2001-2006 (Panel), 2006, 2008

The data presented in the table does not speak of a uniform decrease in the overall image of party leaders, as found out with regard to the percentage of party identifiers. Yet, one cannot overlook the fact that this time we have included two additional time points (1994 and 2004). And we did so on purpose: given the nature of the macro level analysis that will soon follow, it seemed appropriate to increase our $n$ as much as possible. Figure 3 presents the trends of both 'aggregate partisanship' and 'overall leader image' in six different time-points (e.g., 1994, 1996, 2001, 2004, 2006, 2008). The data on aggregate partisanship for 1994 and 2004 comes, respectively, from Eurobarometer 41 and the second wave of ITANES panel 20012006. 
The Dinamics of (Personalized) Party Identification in the Second Italian Republic - Diego Garcia

FIGURE 3 - Aggregate Partisanship and 'Overall Image of Leaders', 1994-2008

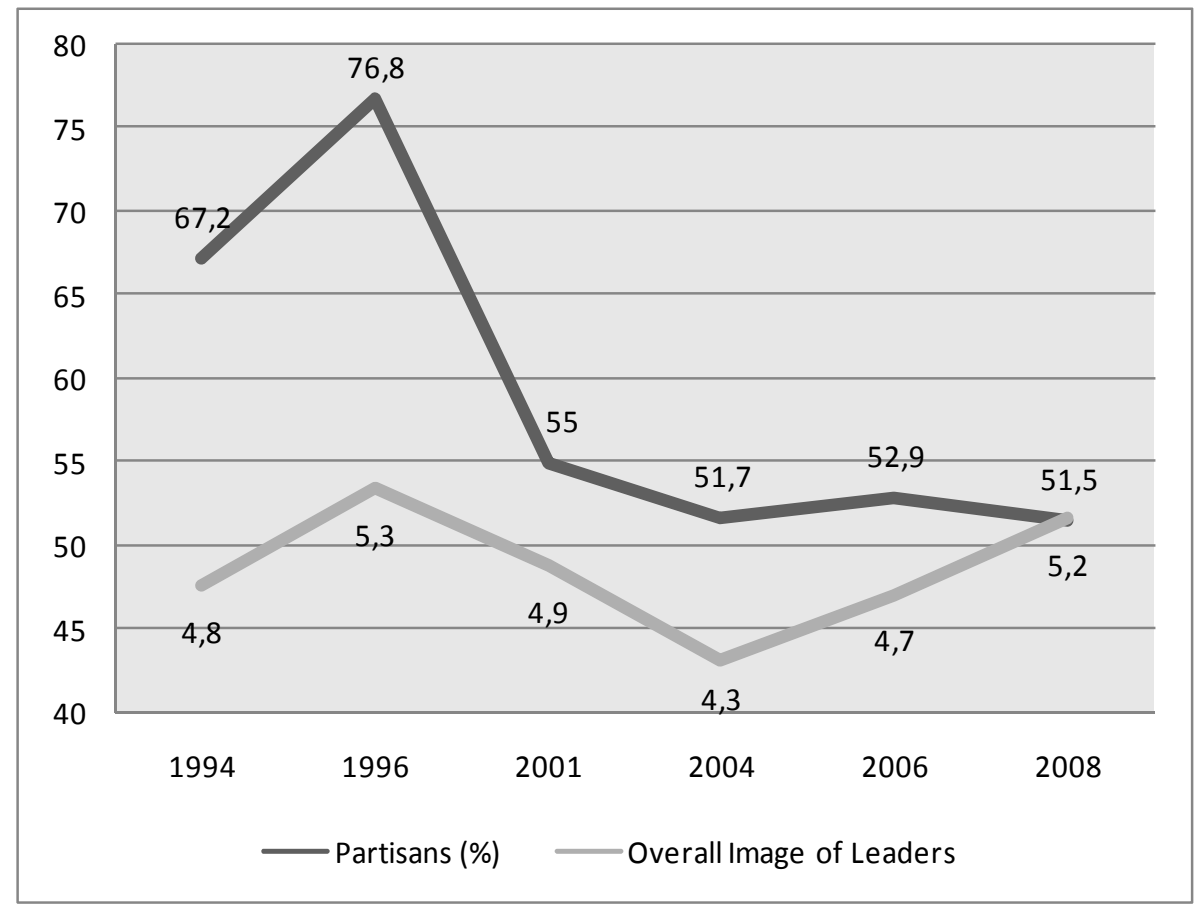

SOURCE: Eurobarometer 41; ITANES 1994, 1996, 2001-2006 (Panel), 2006, 2008

At this point, also partisan dealignment appears less uniform in its development. Yet, we could expect party identifiers in 1994 to be less than in 1996 - this being in line with the 'orthodox' assumption that feelings of attachment with a political group develop with time (Converse et al. 1960). And while the period between 2001 and 2006 previously appeared as a downwards trend between two time-points, we see now that in 2004 the number of partisans was slightly lower than in 2006 - yet, not so lower (roughly one percentage point) to disturb the general trend. But what matters the most, the trend-lines for the period 19942006 are now entirely compatible. Every time the 'overall image of leaders' goes up (or down), so do the percentage of party identifiers. The correlation coefficient (Pearson's $r$ ) between the two trends in the period is $.81(n=5)$. However, the correlation gets strongly depressed if we include the measurements relative to 2008 in the analysis $(r=.55)$, and this for a clearly visible reason: between 2006 and 2008 the 'overall image of the leaders' increased sensibly, but the percentage of partisans did not augment by any means. At a first glance, this would seem a definite disconfirmation of our hypothesis. Yet I contend that it is indeed the strongest proof marshaled in support of our theory. In 2006, roughly 80 percent of partisans were identified with a party that two years after would not have existed anymore. Since we know partisan attachments to develop with time, we could have expected a much sharper decrease in party identifiers than the one-point-something percent actually found. According to our findings the image of party leaders is among the strongest determinants of alignment (along with self/party left-right distance, but in aggregate it is mathematically impossible to reduce such distance lessening the number of parties). Hence, if aggregate 
The Dinamics of (Personalized) Party Identification in the Second Italian Republic - Diego Garzia partisanship in 2008 was substantially resilient notwithstanding a wholly renewed political offer, we can assert with a certain degree of confidence that this would have not been the case without a significant increase in the public's perception of party leaders. In other words, in 2008 it was the improved image of the leaders to prevent a major fall in aggregate partisanship (as we would have expected otherwise).

\section{CONCLUSIONS}

Recall the definition of personalization of politics provided above: "a process in which the political weight of the individual actor in the political process increases over time, while the centrality of the political group (i.e., political party) declines" (Rahat and Sheafer 2007: 65). The findings of our analysis carry strong support for the 'personalization hypothesis' in the context of the Second Italian Republic, and in particular with respect to the increasingly 'personalized' dynamics of party identification. We found that the weight of party leaders as a determinant of party identification equals substantially that of ideological proximity. What is more, party leaders' image is even a stronger (indeed, the strongest) determinant of partisanship instability - which is in turn conductive to partisan dealignment. These results demonstrate that party leaders bear a stronger role in shaping (rather than being shaped by) political attitudes than is often supposed (e.g., Barisione 2006; Barisione and Castellani 2008). In the final section we further advanced an explanation for the decline of aggregate partisanship in the period 1996-2008, based on the changing perception of leaders as a whole ('overall image of leaders'): a fairly strong correlation between the two is emerged. But most of all, we could ascribe to the improved image of party leaders the fact that in 2008 aggregate partisanship 'held' notwithstanding a sweeping change in the political scene. If we are to advance a reason for the ameliorated image of the leaders in that year, it is probably to be found in the way the political battle has been fought. Walter Veltroni's strategy to keep it calm' (Legnante and Sani 2008: 29) had undoubtedly a role in promoting a competition freed from the so-called 'demonization of the enemy', which consisted in a minor number of personal attacks - and in turn resulted in a less generalized erosion of 'image capital'.

One final point seems in order. The personalized dynamics of party identification as outlined in this paper shed a not so assuring light on the spread of open primaries among Italian coalitions (i.e., Unione) and parties (i.e., Partito Democratico). So far, primary elections of the left has been mainly a way to provide leaders in pectore with a piece of 'popular legitimacy' (in both 2006 and 2008 Romano Prodi and Walter Veltroni faced no serious challengers for the leadership of Unione and PD respectively). However, these leaders were already chosen by their respective coalition/party as the less divisive figure around (in this respect, Prodi's leadership is the most telling example). The higher it will get the competitiveness of such contests, the less they will be likely to result in the election of a 
The Dinamics of (Personalized) Party Identification in the Second Italian Republic-Diego Garcia

unifying figure. We showed in this paper the high instability of partisan ties in the Second Italian Republic, as well as the strong impact of party leader evaluation on such process. Also, we know from the last fifteen years of Italian politics what the 'divisive leader' implies: some will love him, some others will hate him. The risk for internally democratic parties is obvious: the more divisive its popularly elected leader will be, the higher the chances to lose partisans $\operatorname{are}^{11}$.

\footnotetext{
${ }^{11}$ In this respect, the last primary election held in October 2009 by the Partito Democratico is quite telling, with the election of Pierluigi Bersani almost instantly resulting in the depart by one of the party's founding fathers, Francesco Rutelli, in open disagreement with the leftish direction the party is supposed to take under such leadership.
} 


\section{REFERENCES:}

Barisione, M. (2006) "Il richiamo debole del leader di coalizione”. In ITANES (ed.) Dov'è la Vittoria? Bologna: Il Mulino.

Barisione, M. and Castellani, P. (2008) “L'offerta personalizzata degli sfidanti”. In ITANES (ed.) Il Ritorno di Berlusconi. Bologna: Il Mulino.

Bean, C. (1993) The electoral influence of party leader images in Australia and New Zealand. Comparative Political Studies 26: 111-132.

Bean, C. and Mughan, A. (1989) Leadership effects in parliamentary elections in Australia and Britain. American Political Science Review 83: 1165-79.

Bellucci, P. (2007) Changing Models of Electoral Choice in Italy. Modern Italy 12: 55 - 72.

Berglund, F.; Holmberg, S.; Schmitt, H.; Thomassen, J. (2005) "Party Identification and Party Choice", in Jacques Thomassen (Ed.), The European Voter. A Comparative Study of Modern Democracies, pp. 106-124. Oxford, Oxford University Press.

Budge, I.; Crewe, I.; Farlie, D. (1976) Party Identification and Beyond. John Wiley and Sons. Butler, D. and Stokes, D.E. (1969) Political Change in Britain. London: Macmillan.

Calise, M. (2000) Il Partito Personale. Roma-Bari: Laterza.

Calise, M. (2004) Un decennio presidenziale. In Comunicazione Politica 5: 25-36.

Calise, M. (2005) “Presidentialization. Italian Style”. In Poguntke and Webb (eds.) The Presidentialization of Politics in Democratic Societies. Oxford: Oxford University Press.

Campbell, A. ; Converse, P. E.; Miller, W.; Stokes, D. (1960) The American Voter. Chicago and London, The University of Chicago Press.

Campbell, A., Valen, H. (1966) "Party Identification in Norway and the United States". In Campbell, Converse, Miller and Stokes (eds.) Elections and the Political Order. New York: Wiley.

Campus, D.; Pasquino, G. (2006) Leadership in Italy: The Changing Role of Leaders in Elections and in Government. Journal of Contemporary European Studies 14: 25-40.

Clarke, H.D., Jenson, J., LeDuc, L. and Pammett, J.H. (1979) Political Choice in Canada. Toronto: McGraw-Hill, Ryerson.

Cotta, M.; Verzichelli, L. (2007) Political Institutions in Italy. Oxford: Oxford University Press.

Crewe, I. (1976) "Party Identification Theory and Political Change in Britain", in Budge, I.; Crewe, I.; Farlie, D. (eds.) Party Identification and Beyond. John Wiley and Sons.

Crewe, I., \& King, A. (1994) "Did Major Win? Did Kinnock Lose? Leadership Effects in the 1992 Election”. In Labour's Last Chance? The 1992 Election and Beyond, eds. A. Heath, R. Jowell \& J. Curtice. Aldershot: Dartmouth.

Dalton, R. J. (1984) Cognitive Mobilization and Partisan Dealignment in Advanced Industrial Democracies. The Journal of Politics, Vol. 46, No. 1 (Feb., 1984), pp. 264-284 
The Dinamics of (Personalized) Party Identification in the Second Italian Republic - Diego Garcia

Dalton, R. J. (2000) “The Decline of Party Identifications”, in R. J. Dalton, M. P. Wattenberg (Eds.), Parties without Partisans, Political Change in Advanced Industrial Democracies. Oxford, Oxford University Press.

Dalton, R. J. (2004) Democratic Challenges, Democratic Choices. Oxford: Oxford University Press.

Dalton, R. J.; Wattenberg, M.P. (2000) Parties Without Partisans: Political Change in Advanced Industrial Democracies. Oxford: Oxford University Press.

Dalton, R., Weldon, S. (2004) L'immagine dei partiti politici nell'opinione pubblica: Un male necessario? [Public images of political parties: A necessary evil?]. Rivista Italiana Di Scienza Politica 3: 381-404.

Fabbrini, S. (2000) The Presidentialization of Italian Local Government. Paper for ECPR, Copenhagen, April 14-19, 2000.

Farrell, D.; Webb, P. (2000) "Political Parties as Campaign Organizations" in Dalton and Wattenberg, Parties without Partisans: Political Change in Advanced Industrial Democracies. Oxford: Oxford University Press.

Fiorina, M. F. (1981) Retrospective Voting in American National Elections. New Haven: Yale University Press.

Gilbert, M. (1995) The Italian Revolution: The End of Politics, Italian Style? Boudler: Westview Press.

Graetz, B.; McAllister, I. (1987) Political leadership and electoral outcomes in Britain, 19741983. Comparative Political Studies 19: 484-507.

Hazan, R. (2006) "Metodi di Selezione dei Candidati: le Conseguenze delle Elezioni Interne ai Partiti”, in Bardi (ed.) Partiti e Sistemi di Partito, Bologna, Il Mulino

Holmberg, S. (1994) "Party Identification Compared across the Atlantic", in M. Kent Jennings, T. Mann (Eds.), Elections at Home and Abroad, pp. 93-122, Ann Arbor, The University of Michigan Press.

Inglehart, R.; Klingemann, H. (1976) "Party Identification, Ideological Preference and the Left-Right Dimensions among Western Mass Publics”, in Ian Budge, Ivor Crewe, Dennis Farlie, (eds) Party Identification and Beyond. John Wiley and Sons.

Kaase (1976) "Party Identification and Voting Behavior in the West German Election of 1969”, in Budge, I.; Crewe, I.; Farlie, D. (eds.) Party Identification and Beyond. John Wiley and Sons.

Katz, R. (2003) "Reforming the Italian Electoral Law, 1993". In Mix-Member Electoral Systems, eds. Shugart, M.S. and Wattenberg, P. Oxford: Oxford University Press.

King, A. (2002) Leaders' Personalities and the Outcomes of Democratic Elections. Oxford: Oxford University Press.

Lanoue, D.J.; Headrick, B. (1994) Prime ministers, parties and the public. Public Opinion Quarterly 58: 191-209. 
The Dinamics of (Personalized) Party Identification in the Second Italian Republic - Diego Garzia

Legnante, G.; Sani, G. (2008) “Una breve campagna elettorale”. In ITANES (ed.) Il Ritorno di Berlusconi. Bologna: Il Mulino.

Markus, G.B.; Converse, P.E. (1979) A Dynamic Simultaneous Equation Model of Electoral Choice. American Political Science Review 73: 1055-1070.

Mazzoleni, G. (1996) "Patterns and Effects of Recent Changes in Electoral Campaigning in Italy”. In Politics, Media, and Modern Democracy: An International Study of Innovations in Electoral Campaigning and Their Consequences, eds. Mancini, P. and Swanson, D.L. Westport, CT: Praeger.

McAllister, I. (2003) Prime ministers, opposition leaders and government popularity in Australia. Australian Journal of Political Science 38: 259-77.

McAllister, I. (2007) The Personalization of Politics. In Oxford Handbook of Political Behavior, eds. R.J. Dalton and H.D. Klingemann. Oxford: Oxford University Press.

Miller, W. E.; Shanks, J. M. (1996) The New American Voter. Cambridge, Mass.: Harvard University Press.

Morlino, L. (1996) Crisis of parties and change of party system in Italy. Party Politics 2: 5-30. Mughan, A. (2000) Media and the Presidentialization of Parliamentary Elections. London: Palgrave.

Parisi, A.; Pasquino, G. (1977) "Relazioni partiti-elettori e tipi di voto", in A. Parisi and G. Pasquino (Eds.) Continuità e mutamento elettorale in Italia. Bologna: Il Mulino.

Perrucci, T.; Villa, M. (2004) "Italy". In Lange and Ward (eds.) The Media and Elections. Mahwah: Lawrence Erlbaum Associates.

Poguntke, T.; Webb, P. (2005) The Presidentialization of Politics in Democratic Societies. Oxford: Oxford University Press.

Poli, E. (2001) Forza Italia. Strutture, leadership e radicamento territoriale. Bologna: Il Mulino.

Rahat, G.; Shaefer, T. (2007) The Personalization(s) of Politics: Israel, 1949-2003. Political Communication 24: 65-80.

Sani, G. (2002) "Il Fattore B". In Le ragioni dell'elettore. Perché ha vinto il centro-destra nelle elezioni italiane del 20o1, eds. M. Caciagli and P. Corbetta. Bologna: Il Mulino.

Shively, W. P. (1979) The Development of Party Identification among Adults: Exploration of a Functional Model. The American Political Science Review 73: 1039-1054.

Shugart, M.; Wattenberg, M.P. (2001) Mixed-Member Electoral Systems: The Best of Both Worlds? Oxford: Oxford University Press.

Stokes, D. (1966) Some Dynamic Elements of Contest for the Presidency. American Political Science Review 60: 19-28.

Swanson, D.L.; Mancini, P. (1996) Politics, Media, and Modern Democracy: An International Study of Innovations in Electoral Campaigning and Their Consequences. Westport, CT: Praeger. 
The Dinamics of (Personalized) Party Identification in the Second Italian Republic - Diego Garcia

Thomassen, J. (1976) "Party Identification as a Cross-National Concept: Its Meaning in The Netherlands", in Budge, I.; Crewe, I.; Farlie, D. (eds.) Party Identification and Beyond. John Wiley and Sons.

Thomassen, J.; Rosema, M. (2009) "Party Identification Revisited", in J. Bartle and P. Bellucci (eds.) Political Parties and Partisanship. Social identity and individual attitudes. London and New York: Routledge.

Wattenberg, M. P. (1991) The Rise of Candidate-Centered Politics. Cambridge, Mass: Harvard University Press. 